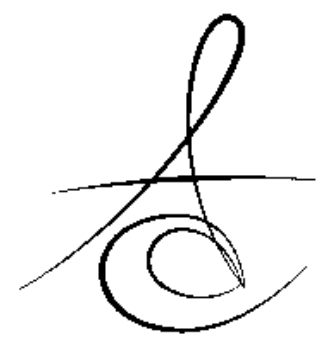

\title{
THE IMPACT OF HYPODONTIA ON ORAL HEALTH-RELATED QUALITY OF LIFE
}

\author{
HİPODONTİNİN AĞIZ Dİş SAĞLIĞINA BAĞLI YAŞAM KALİTESİ ÜZERİNE \\ ETKİsí
}

\author{
Dr. Öğr. Üyesi Sultan KELEŞ* \\ Araş.Gör.Dt. Sıla YILMAZ* \\ Prof.Dr. Filiz ABACIGİL ${ }^{* * *}$
}

\author{
Araş.Gör.Dt. Hülya YILMAZ* \\ Doç. Dr. Sera ŞİMŞEK DERELİoĞLU**
}

Makale Kodu/Article code: 3527

Makale Gönderilme tarihi: 19.12 .2017

Kabul Tarihi: 02.02 .2018

\section{ABSTRACT}

Aim: The aim of this study was to determine the impact of mild congenital hypodontia on oral healthrelated quality of life in children aged from 11-14 years by considering their own statements.

Materials and Methods: One hundred and thirty 11to 14-year-old children were included in this crosssectional study. The control group (G-C) was composed of 65 patients without hypodontia and the hypodontia group (G-H) was composed of 65 patients with different numbers of missing teeth. After oral examination, children were asked to fill out the Child Perceptions Questionnaire (CPQ 11-14) to evaluate the oral health-related quality of life. The number/ numbers of missing teeth, the segment of missing teeth, and demographic data were recorded. The data were analyzed using Student's t-test, the chi square test, and Pearson correlation analysis.

Results: The mean age of children that participated in this study was $12.5+1.07$ (55\% girls, $45 \%$ boys). A total of 117 teeth were missing in patients with hypodontia. The mean number of missing teeth in patients with hypodontia was $1.77 \pm 0.65$. The mean oral health-related quality of life score of the groups was $36.3 \pm 16.7$ for control group and $34.7 \pm 18.1$ for hypodontia group ; the difference between the groups was not statistically significant $(p>0.05)$. Significant correlation was not detected between the oral healthrelated quality of life and the number of missing teeth in patients with hypodontia $(r=-0.008, p=0.95)$.

Conclusion: Missing teeth had no impact on oral health-related quality of life in patients with mild hypodontia due to the small numbers of missing teeth in the experimental group.

Keywords: Oral health related quality of life, hypodontia, children

\section{ÖZ}

Amaç: Bu çalışmanın amacı konjenital hipodontinin 11-14 yaş arasındaki çocuklarda ağız diş sağlığına bağlı yaşam kalitesi üzerindeki etkisini kendi beyanlarına dayalı olarak belirlemektir.

Gereç ve Yöntem: Bu kesitsel çalışmaya 11-14 yaş arası 130 çocuk dahil edilmiştir. Kontrol grubunu (G-K) hipodontisi olmayan 65 hasta, hipodonti grubunu (G$\mathrm{H}$ ) ise farklı sayılarda diş eksikliği olan 65 hasta oluşturmuştur. Diş muayenesi tamamlanan hastalara ağız diş sağlığına bağlı yaşam kalitesinin belirlenmesinde kullanılan Çocuk Algılama Anketi (CPQ 11-14) uygulanmıştır. Eksik diş ve/veya dişlerin sayısı, bulunduğu bölge ve demografik veriler kaydedilmiştir. Veriler tanımlayıc istatistikler, student t testi, ki-kare testi ve Pearson korelasyon analiziyle test edilmiştir.

Bulgular: Çalışmaya katılan çocukların ortalama yaşları $12,5 \pm 1,07$ 'dir (\%55 kı, \%45 erkek). Hipodonti hastalarının toplamda 117 dişinin konjenital olarak eksik olduğu saptanmıştır. Hipodonti grubundaki eksik diş sayısı ortalaması $1,77 \pm 0,65$ olarak belirlenmiştir. Grupların ortalama ağız diş sağığına bağlı yaşam kalitesi skoru kontrol grubu için $36,3 \pm 16,7$, hipodonti grubu için $34,7 \pm 18,1$ olarak hesaplanmıştır. Grupların ağız diş sağlığına bağlı yaşam kaliteleri arasında istatistiksel olarak anlamlı fark saptanmamıştır ( $p>0.05$ ). Hipodontisi olan hastalarda ağız diş sağlığına bağlı yaşam kalitesi ile eksik diş sayısı arasında anlamlı korelasyon saptanmamıştır $(r=-0.008, p=0.95)$.

Sonuç: Hafif seviyede konjenital hipodonti 11-14 yaş arası çocuklarda ağız diş sağlığına bağlı yaşam kalitesi üzerinde etkili olmamıştır. Bu durum çalışılan gruptaki eksik diş sayısının düşük sayıda olmasından kaynaklanmış olabilir.

Anahtar Kelimeler: Ağız diş sağlığına bağlı yaşam kalitesi, hipodonti, çocuk 
Atatürk Üniv. Diş Hek. Fak. Derg.

] Dent Fac Atatürk Uni

Cilt:28, Sayı:2, Yıl: 2018, Sayfa, 222-227
KELEŞ, YILMAZ, YILMAZ,

ŞİMŞEK DERELİĞLU, ABACIGİL

\section{INTRODUCTION}

Hypodontia is the term used for defining the congenital absence of one or multiple primary or permanent teeth excluding the third molars. ${ }^{1}$ Aetiological factors for hypodontia has a wide range from hereditary to environmental factors. Hypodontia severity is categorised as mild where one to three teeth are absent; moderate where four to six teeth are absent; and severe when more than six teeth are absent. $^{2}$ Usually permanent dentition is affected and it is seen rarely in the primary dentition. When primary dentition is affected, the absence is seen in the incisor region often leading to the agenesis of the succeeding permanent teeth . ${ }^{3}$

According to studies, this developmental anomaly affects between $5.3 \%$ and $7.9 \%$ of children, excluding the third molars. ${ }^{4}$ The prevalence may differ based on the study populations sampling methods, sample size and distribution of age groups and racial differences. ${ }^{5}$ Tunc et al. ${ }^{6}$ reported that the prevalence of hypodontia was $8.7 \%$ in 981 children between the ages of 6 and 12 and that the incidence of hypodontia did not show significant difference between the sexes. In a study carried out by Sökücü et al. on 3586 patients in permanent dentition, the prevalence of hypodontia was found to be $3 \% .{ }^{7}$

Although congenital hypodontia is one of the most frequently encountered anomalies, it is not considered as an important health problem but it has been reported that hypodontia may cause disorders in speech, aesthetics and muscle function. ${ }^{8}$ It has been shown in several studies that hypodontia may have adverse effects on oral health related quality of life. ${ }^{5}$ Its important to understand the impact of hypodontia on patients' quality of life. Moreover, by understanding the consequences of the condition on daily lives of patients, management of such cases and producing best guidelines is also possible.

Oral health related quality of life can be defined as 'the impact of oral disorders on aspects of everyday life that are important to patients and persons, with those impacts being of sufficient magnitude, whether in terms of severity, frequency or duration to affect an individual's perception of their life overall'. ${ }^{9}$ Considering developmental disorders, lots of different questionnaires have been developed to obtain quality of life information of patients. One of them is the Child Perceptions Questionnaire (CPQ). $\mathrm{CPQ}$ consists of 37 questions divided into four parts; six items relating to oral symptoms, nine items on functional limitations, nine items on emotional wellbeing and 13 items on social well-being. These questions assess the child's opinions about his/her dental appearance and behavioural problems. ${ }^{10}$

Although there are many studies on prevalence, aetiology and management of tooth agenesis only a few studies were carried out considering functional, social and behavioural aspects. $^{11-12}$ In a retrospective study conducted by Hobkirk, the concerns of 451 patients with hypodontia were analyzed and it was concluded that the most common complaints were spacing and poor aesthetics. $^{11}$

No studies exist in our country examining the impact of congenital hypodontia on oral health related quality of life in 11-14 year old children. Therefore, the aim of this study was to determine the impact of congenital hypodontia on oral health-related quality of life of children aged between 11-14 years using Child Perceptions Questionnaire (CPQ 11-14).

\section{MATERIALS AND METHODS}

The study was approved by the Ethics Committee of the Adnan Menderes University (2016/1033) and the participants/caregivers signed a written informed consent prior to participation. One hundred and thirty 11- to 14-year-old children who applied for oral examination at the Adnan Menderes University Faculty of Dentistry Department of Pediatric Dentistry were included in this cross-sectional study.

The control group (G-C) was composed of 65 patients without hypodontia and the hypodontia group (G-H) was composed of 65 patients with at least one congenitally missing tooth. ${ }^{13,14}$ The inclusion criteria were ; absence of systemic and developmental disorders, no previous treatment for hypodontia, at least one absent tooth for hypodontia group. The exclusion criteria for the study were; craniofacial anomaly, previous treatment for hypodontia, restorations in the upper labial segment, presence of untreated caries, periodontal disease or non-Turkish speaking children.

\section{Data Collection}

After full mouth examination, children were

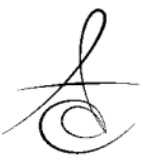


Atatürk Üniv. Diş Hek. Fak. Derg.

J Dent Fac Atatürk Uni

Cilt:28, Sayı:2, Yıl: 2018, Sayfa, 222-227

asked to fill out the Child Perceptions Questionnaire (CPQ 11-14), which is used for assessing the oral health-related quality of life.

CPQ 11-14 contains 37 questions and four health domains: oral symptoms, functional limitation, emotional well-being, and social well-being. The questions are about the frequency of events experienced by children within past 3 months, with the following options: never $=0$; once or twice $=1$; sometimes $=2$; often $=3$ and everday or almost every day $=4$. Summing the response numbers generates domain scores and an overall $\mathrm{CPQ}$ score. All questionaires were self-completed by the children. The number/numbers of missing teeth, the segment of missing teeth, retained primary teeth and demographic data were recorded.

\section{Statistical Analysis}

The sample size (65 patients per group) was determined by the G-power software based on a study by Laing et al 13 with a power of $80 \%$ using a t-test to compare means with an alpha value of .05. All data were saved in a Microsoft Excel database and exported to the Statistical Package for the Social Sciences program for Windows (SPSS 20.0, SPSS Inc., Chicago, USA) for statistical analysis.

Overall CPQ 11-14 score and domain additive scores for each child were calculated by summing the response codes for the questions. Higher scores incicate greater impact on oral health related quality of life. Scores were also generated by counting the number of the impacts reported 'often' or 'everyday/Almost everyday'for the scale as a whole and the four domain. These count scores provide to express the impact of the hypodontia in terms of prevalance. All data were subjected to the Kolmogorov-Smirnov test for normality. Descriptive statistics are presented as percentages and means \pm standard deviations. Student-t tests were used to compare the parametric continuous variables of independent groups. Chi-square tests were used to compare categorical variables between the two groups. Correlation between the number of missing teeth and oral health related quality of life was tested with Pearson Correlation Analysis. A 5\% type-1 error level was used to infer statistical significance.
KELES, YILMAZ, YILMAZ,

ŞİMŞEK DERELİOĞLU, ABACIGİL

\section{RESULTS}

The mean age of children participated in this study was $12.5 \pm 1.07$ ( $55 \%$ girls, $45 \%$ boys). A total of 117 teeth were missing in patients with hypodontia. There were no statistically significant difference between groups with regard to age and gender. The mean number of missing teeth in patients with hypodontia was $1.77 \pm 0.65$ with a range $1-3$. The majority of patients had one absent tooth. The lower second premolars (45\%) and the upper lateral incisor $(39.1 \%)$ were the most frequently absent teeth. Primary teeth retention was seen in $22.3 \%(n=29)$ of the missing teeth. The sample characteristics is shown in Table 1.

Table 1. Sample characteristics

\begin{tabular}{|c|c|c|c|}
\hline & $\begin{array}{c}\text { Control } \\
\text { Group (G- } \\
\text { C) }\end{array}$ & $\begin{array}{l}\text { Hypodontia } \\
\text { Group (G-H) }\end{array}$ & $\begin{array}{c}\mathbf{P} \\
\text { Value }\end{array}$ \\
\hline \multicolumn{4}{|l|}{ Gender n(\%) } \\
\hline Female & 34 & $38(\% 58.5)$ & 0.56 \\
\hline Male & 31 & $27(\% 41.5)$ & 0.59 \\
\hline \multicolumn{4}{|l|}{ Age } \\
\hline \multicolumn{4}{|l|}{$\begin{array}{l}\text { Segment of } \\
\text { missing teeth }\end{array}$} \\
\hline Anterior & - & $31(47.7)$ & - \\
\hline Posterior & & $34(52.3)$ & \\
\hline \multicolumn{4}{|l|}{ Primary teeth } \\
\hline Yes & & $29(\% 22.3)$ & \\
\hline No & & 101(77.7) & \\
\hline \multicolumn{4}{|l|}{$\begin{array}{l}\text { Number of } \\
\text { missing teeth }\end{array}$} \\
\hline 1 & & $23(\% 35.4)$ & \\
\hline 2 & & $34(\% 52.3)$ & \\
\hline 3 & & $8(\% 12.4)$ & \\
\hline
\end{tabular}

The mean oral health-related quality of life score of the groups was $36.3 \pm 16.7$ for control group and $34.7 \pm 18.1$ for hypodontia group ; the difference between the groups was not statistically significant $(t=-0.88, p=0.37$ ) (Table 3).

There was no statistically significant difference in the domains of $\mathrm{CPQ}$ between the groups in terms of gender, scale in terms of gender, segment of missing teeth, number of missing teeth, primary teeth retention ( $p>0.05$ ) (Table 2 ).

The prevalance of quality of life impacts as reported using the CPQ11-14 are shown in table 4 . There was no statistically significant difference

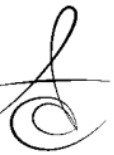


Atatürk Üniv. Diş Hek. Fak. Derg.

] Dent Fac Atatürk Uni

Cilt:28, Sayı:2, Yıl: 2018, Sayfa, 222-227

between the groups in terms of the prevalance of the impacts ( $p>0.05)$.

Significant correlation was not detected between the oral health-related quality of life and the number of missing teeth in patients with hypodontia $(r=-0.008, p=0.95)$.

Table 2. The comparison of oral health related quality of life scores according to gender, primary teeth retention and segment of missing teeth in hypodontia group.

\begin{tabular}{lccccc}
\hline & $\begin{array}{c}\text { Oral } \\
\text { ymptoms }\end{array}$ & $\begin{array}{c}\text { Eunctional } \\
\text { Limitation }\end{array}$ & $\begin{array}{c}\text { imotional } \\
\text { Well- } \\
\text { Being }\end{array}$ & $\begin{array}{c}\text { Social } \\
\text { Well- } \\
\text { Being }\end{array}$ & $\begin{array}{c}\text { otal CPQ } \\
\text { Score }\end{array}$ \\
\hline Gender & & & & & \\
Female & $7.6 \pm 4.2$ & $8.9 \pm 5.3$ & $9.9 \pm 6.9$ & $7.4 \pm 7.7$ & $33.9 \pm 18.8$ \\
Male & $7.4 \pm 3.5$ & $7.7 \pm 4.6$ & $7.6 \pm 5.2$ & $7.9 \pm 6.1$ & $30.7 \pm 15.4$ \\
P & 0.74 & 0.16 & 0.04 & 0.69 & 0.29 \\
\hline Primary & & & & & \\
teeth & & & & & \\
retention & & & & & \\
Yes & $7.1 \pm 3.7$ & $7.6 \pm 5.4$ & $9.0 \pm 7.2$ & $6.4 \pm 8.1$ & $30.1 \pm 21.1$ \\
No & $7.6 \pm 3.9$ & $8.6 \pm 4.9$ & $8.9 \pm 6.1$ & $8.1 \pm 7.3$ & $33.5 \pm 16.2$ \\
P & 0.49 & 0.32 & 0.92 & 0.29 & 0.40 \\
\hline Segment & & & & & \\
of & & & & & \\
missing & & & & & \\
teeth & $7.3 \pm 4.1$ & $8.0 \pm 5.7$ & $7.7 \pm 7.3$ & $7.1 \pm 8.6$ & $30.1 \pm 20.3$ \\
Anterior & $7.3 \pm 3.8$ & $8.0 \pm 4.3$ & $10.1 \pm 6.2$ & $8.2 \pm 7.4$ & $33.5 \pm 16.8$ \\
Posterior & 0.49 & 0.32 & 0.92 & 0.29 & 0.40 \\
P & & & & & \\
\hline
\end{tabular}

Table 3. Comparison of the CPQ scores of the groups in terms of domains

\begin{tabular}{lccc}
\hline $\begin{array}{l}\text { Domain of CPQ } \\
\mathbf{1 1 - 1 4}\end{array}$ & $\begin{array}{c}\text { Control Group } \\
\text { (G-C) }\end{array}$ & $\begin{array}{c}\text { Hypodontia } \\
\text { Group (G-H) }\end{array}$ & $\begin{array}{c}\text { P } \\
\text { Value }\end{array}$ \\
\hline Oral Symptoms & $8.6 \pm 3.3$ & $9.3 \pm 3.9$ & 0.31 \\
\hline $\begin{array}{l}\text { Functional } \\
\text { Limitation }\end{array}$ & $9.8 \pm 5.2$ & $10.3 \pm 4.8$ & 0.62 \\
\hline $\begin{array}{l}\text { Emotional } \\
\text { Well-Being }\end{array}$ & $8.5 \pm 5.9$ & $8.6 \pm 5.6$ & 0.94 \\
\hline $\begin{array}{l}\text { Social Well- } \\
\text { Being }\end{array}$ & $7.7 \pm 8.1$ & $8.1 \pm 6.4$ & 0.74 \\
\hline $\begin{array}{l}\text { Total CPQ } \\
\text { score }\end{array}$ & $34.7 \pm 18.1$ & $36.3 \pm 16.7$ & 0.60 \\
\hline
\end{tabular}

Table 4. Prevalance of the impact of patients in the groups and their comparisons

\begin{tabular}{|l|c|c|c|}
\hline \multirow{2}{*}{ Domain/Subdomain } & \multicolumn{2}{|c|}{$\begin{array}{c}\text { Prevalance of impact } \\
\text { (\%) }\end{array}$} & \multirow{2}{*}{ P value } \\
\cline { 2 - 3 } & $\begin{array}{c}\text { Control } \\
\text { group }\end{array}$ & Hypodontia & \\
\hline CPQ11-14 & 49.0 & 51.0 & 0.41 \\
\hline Oral symptoms & 47.7 & 50.8 & 0.43 \\
\hline $\begin{array}{l}\text { Functional } \\
\text { limitation }\end{array}$ & 53.8 & 63.1 & 0.18 \\
\hline $\begin{array}{l}\text { Emotional well- } \\
\text { being }\end{array}$ & 33.8 & 38.5 & 0.35 \\
\hline Social well-being & 30.8 & 36.9 & 0.28 \\
\hline *Per cent with one or more items scored 'often' or 'everyday /almost everyday'. \\
\hline
\end{tabular}

KELES, YILMAZ, YILMAZ,

ŞİMŞEK DERELIOĞLU, ABACIGİL

\section{DISCUSSION}

This cross-sectional study was conducted to investigate the impact of hypodontia on oral health related quality of life in children between ages 11-14. The present study did not find a statistically significant difference in terms of oral health related quality of life scores between the hypodontia group and control group. The mean CPQ scores and the prevalence of the impact of the groups were similar to each other.

In the present study, we used CPQ11-14 to evaluate the oral health related quality of life of the children since it was developed for assessing the impact of oral conditions in adolescence. The questionnaire has been demonsrated to be valid in different countries including Canada ${ }^{10}$, Hong Kong ${ }^{5}$, the United Kingdom ${ }^{15}$ and Turkey ${ }^{16}$. The CPQ11-14 was used to ealuate the impact of hypodontia on oral health related quality of life in previous studies .5,12,17

The severity and prevalence of hypodontia in permanent dentition has been reported to be $0.3 \%$ to $10.1 \%$ due to population studied. ${ }^{7,18,19}$ Tunc et al. ${ }^{19}$ determined that the most of the children (79\%, 84 in girls and 54 in boys) with congenitally absent tooth aged 5.3 to 12.5 years had absence of either 1 tooth or 2 teeth in the north part of Turkey. Similar to their study, most of the children had hypodontia of either 1 tooth or 2 teeth in our hypodontia group. Only $12.4 \%$ of children had 3 missing teeth. This low severity of hypodontia may explain the reason why there was no statistically significant impact of hypodontia on oral health related quality of life in this study.

In our hypodontia sample, $50.8 \%$ reported impact on oral symtoms, $63.1 \%$ reported impact on functional limitation, $38.5 \%$ reported impact on emotional well-being, $36.9 \%$ reported impact on social well-being. These prevalences were higher than control group but there was no statistically significant difference between the groups. Jokovic et al. ${ }^{10}$ evaluated the impact of oligodontia on the oral health related quality of life in children between the age 1114 and the subjects reported $28 \%$ oral symptoms , $61 \%$ experienced functional limitations , $19 \%$ reported impacts on emotional well-being and $17 \%$ impacts on social well-being. Kotecha et al. ${ }^{17}$ investigated the psychosocial impact of hypodontia on 43 children with mild hypodontia, 43 with a severe form and a control group of 30 children without hypodontia and found 
Atatürk Üniv. Diş Hek. Fak. Derg.

J Dent Fac Atatürk Uni

Cilt:28, Sayı:2, Yıl: 2018, Sayfa, 222-227

statistically significantly differences between hypodontia group and non-hypodontia group. Unlike these studies, no child had severe form of hypodontia in our study, which may explain why CPQ 11-14 scores among the groups did not vary.

The mean number of congenitally missing teeth in hypodontia group was 1.77 and the range of number of missing teeth was 1-3 in the present study. However, the percentage of children with three missing teeth was $12.4 \%$ and was lower than those with 2 missing (52.3\%) teeth. This may have contributed to the lower impact of missing teeth on oral health related quality of life in children with hypodontia compared to other studies. Anweigi et al. ${ }^{20}$ compared the effects of mild to moderate hypodontia on oral health related quality of life in young adults and found that hypodontia has a functional effect on oral health as the age increases. Early primary tooth retention has been shown to modulate the impact of hipodontia on oral health-related quality of life. In our study, primary teeth retention was observed in $22.3 \%$ of the cases. Also, there was no statistically significant difference between the group with retention and the group without retention, while the patients with primary teeth retention had a higher oral health related quality of life scores.

Similar to previous studies, there was no significant difference between the total CPQ11-14 scores of different genders. ${ }^{17}$ Also, the emotional wellbeing subscale in the present study was statistically significantly higher in girls than in boys. The segment with missing tooth in our study did not cause a statistically significant difference on oral health related quality of life.

There were some limitations of the present study. Subjects were taken from a single center and the nature of the study was cross-sectional. During the study period there were no patients refered to our clinic with congenitally missing teeth more than three. Thus, the impact of oral health related quality of life in children with moderate and severe hypodontia could not be detected. There is a need for more longitudinal studies including a larger sample to highlight the impact of hypodontia on oral health related quality of life in adolescents.
KELEŞ, YILMAZ, YILMAZ,

ŞİMŞEK DERELİOĞLU, ABACIGİL

\section{CONCLUSIONS}

There was no significant difference between the CPQ scores of patients with mild hypodontia and patients without hypodontia. Also, there was no significant difference in the prevalence of impacts reported by the patients.

Sultan Keles, ORCID.ID: 0000-0001-7978-8715.

Hulya Yılmaz, ORCID.ID: 0000-0003-0963-1944

Sila Yilmaz, ORCID.ID: 0000-0001-8530-1504

Sera Şimşek Derelioğlu, ORCID.ID: 0000-0001-5192-923X

Filiz Abacigil, ORCID.ID: 0000-0003-4291-0013

\section{REFERENCES}

1. Goodman JR, Jones SP, Hobkirk JA, King PA. Hypodonta 1: Clinical features and the management of mild to moderate hypodontia. Dent Update 1994;21:381-4.

2. Tsai PF, Chiou HR, Tseng CC. Oligodontia- a case report. Quintessence Int 1998;29:191-3.

3. Rushmah M. Hypodontia of the primary and permanent dentition. J Clin Pediatr Dent 1992; 16:121.

4. Rolling S. Hypodontia of permanent teeth in Danish schoolchildren. Eur J Oral Sci 1980;88:3659.

5. Wong A, McMillan A, McGrath C. Oral health-related quality of life and severe hypodontia. J Oral Rehabil 2006; 33:869-73.

6. Tunç EŞ, Koyutürk AE. Karadeniz bölgesi çocuklarında konjenital daimi diş eksikliği prevalansı. Atatürk Üniv Diş Hek Fak Derg 2006; 16:37-40.

7. Sökücü $O$, Ünal $M$, Topcuoğlu $T$, Öztaş N. Çocuklarda daimi dentisyonda hipodonti görülme sıklığı. Acta Odontol Turc 2009;26:33.

8. Scarel RM, Trevilatto PC, Di Hipólito O, Camargo LE, Line SR. Absence of mutations in the homeodomain of the MSX1 gene in patients with hypodontia. Am J Med Genet Part A 2000;92:3469.

9. Cunningham SJ and Hunt NP. Quality of life and its importance in orthodontics. Am J Orthod 2001;28:152-8.

10. Jokovic A, Locker D, Stephens M, Kenny D, Tompson B, Guyatt G. Validity and reliability of a questionnaire for measuring child oral-healthrelated quality of life. J Dent Res 2002;81:459-63.

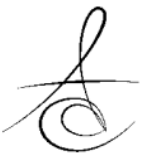


11. Hobkirk J, Goodman J, Jones S. Presenting complaints and findings in a group of patients attending a hypodontia clinic. $\mathrm{Br}$ Dent J 1994;177:337-9.

12. Locker D, Jokovic A, Prakash P, Tompson B. Oral health-related quality of life of children with oligodontia. Int J Paediatr Dent 2010;20:8-14.

13. Laing E, Cunningham SJ, Jones S, Moles D, Gill D. Psychosocial impact of hypodontia in children. Am J Orthod Dentofacial Orthop 2010;137:35-41.

14. Brook PH, Shaw WC. The development of an index of orthodontic treatment priority. Eur J Orthod 1989;11:309-20.

15. Johal A, Cheung M, Marcenes W. The impact of two different malocclusion traits on quality of life. Br Dent J 2007;202:E6-E6.

16. Bekiroglu N, Bakkal M, Ozbay G, Karadeniz PG, Kargul B.Validity and reliability of Child Perception Questionnaire (CPQ 11-14) by Rasch Analysis in Turkish children. Pediatr Dent J 2017;27:14-20.

17. Kotecha S, Turner PJ, Dietrich T, Dhopatkar A. The impact of tooth agenesis on oral health-related quality of life in children. J Orthod 2013;40:122-9.

18. Endo T, Ozoe R, Kubota M, Akiyama M, Shimooka S. A survey of hypodontia in Japanese orthodontic patients. Am J Orthod Dentofacial Orthop 2006;129:29-35.

19. Tunç EŞ, Bayrak Ş, Koyutürk AE. Dental development in children with mild-to-moderate hypodontia. Am J Orthod Dentofacial Orthop 2011;139:334-8.

20. Anweigi L., Allen P, Ziada H. The use of the Oral Health Impact Profile to measure the impact of mild, moderate and severe hypodontia on oral health-related quality of life in young adults. J Oral Rehabil 2013;40:603-8.

\section{Yazışma Adresi}

Sultan KELES

Department of Paediatric Dentistry, Faculty of Dentistry,

Adnan Menderes University,

Aydın, Turkey.

Tel.:0902562133939,

Fax:0902562151918)

e-mail: dtsultank@gmail.com 